See discussions, stats, and author profiles for this publication at: https://www.researchgate.net/publication/313494943

Student-centred learning: a small-scale study of a peer-learning experience in undergraduate translation classes

Article in Language Learning Journal · February 2017

DOI: 10.1080/09571736.2016.1278030

CITATIONS

3

2 authors:

Lucy Bell

University of Surrey

17 PUBLICATIONS 27 CITATIONS

SEE PROFILE
Simon Lygo-Baker

University of Surrey and University of Wisconsin- Madison

79 PUBLICATIONS 1,108 CITATIONS

SEE PROFILE

Some of the authors of this publication are also working on these related projects:

Project The intersections between digital fluency and teaching excellence View project

Project Concept mapping View project 


\section{Student-centred learning: a small-scale study of a peer-learning experience in undergraduate translation classes}

\section{Lucy Bell \& Simon Lygo-Baker}

To cite this article: Lucy Bell \& Simon Lygo-Baker (2019) Student-centred learning: a small-scale study of a peer-learning experience in undergraduate translation classes, The Language Learning Journal, 47:3, 299-312, DOI: 10.1080/09571736.2016.1278030

To link to this article: https://doi.org/10.1080/09571736.2016.1278030

曲 Published online: 08 Feb 2017.

Submit your article to this journal ๘

凹 Article views: 267

View Crossmark data \ulcorner 


\title{
Student-centred learning: a small-scale study of a peer-learning experience in undergraduate translation classes
}

\author{
Lucy Bell $^{\mathrm{a}}$ and Simon Lygo-Baker ${ }^{\mathrm{b}}$ \\ ${ }^{\mathrm{a} S}$ School of English and Languages, University of Surrey, Guildford, UK; ${ }^{\mathrm{b}}$ Department of Higher Education, University \\ of Surrey, Guildford, UK
}

\begin{abstract}
This paper examines student responses to a small-scale pilot of peer learning in undergraduate translation classes. It examines the possible benefits and risks of a learner-centred approach and explores these through feedback from two groups of undergraduate modern language students attending translation classes over a semester at a UK university. With the first group, peer learning was implemented over a six-week period in the second half of the semester; with the second group, only a single 'one-off' peer-learning session was delivered. Feedback from the former group suggests a largely positive experience, while much more resistance and uncertainty are evident in feedback from the latter group. The paper explores possible reasons for successes and pitfalls in peer learning, and recommends some strategies for implementing a learnercentred model as an effective alternative to more traditional forms of translation teaching.
\end{abstract}

\section{KEYWORDS}

Student-centred learning; learner-centred model;

higher education; autonomy; foreign languages;

translation

\section{Introduction}

It has become widely accepted in educational research that the benefits of student-centred learning outweigh the drawbacks (Cornelius-White 2007; McCabe and O'Connor 2013; McMahon 2011; Osborne 2008). Yet, in practice, many university disciplines continue to follow traditional, teachercentred models, which could be interpreted as undermining some of the key principles of UK higher education (HE), not least that of student autonomy (Prosser and Trigwell 1999).

The research described in this article seeks to explore whether, from a student perspective, a learner-centred approach is experienced as positive in the context of an undergraduate translation class. This is a particularly important question in the context of translation studies; despite shifts over the last 50 years in educational theory and practice both within and beyond the area of language learning (Abercrombie and Terry 1978; Bligh 1986; Bruffee 1999; Dickinson 1987; Doyle 2008; Evans 1993; Holec 1979; Little 2007; McCombs 2008; Rogers 1969; Tollefson and Osborn 2007), translation still tends to be taught in a very traditional way in HE contexts in the UK. Whilst Clavijo and Marin (2013) argue that there has been a shift towards a functional approach, they acknowledge authors such as Kiraly (2001) and González-Davies (2004) who argue that pedagogic 'principles' are often not applied within translation teaching strategies.

In the traditional model of translation teaching in $\mathrm{HE}$, classes are spent going through a translation that the students have prepared, following a line-by-line approach whereby teachers ask the students to read out a sentence in turn. Some teachers 'pick' on students, others ask their students to volunteer, and others go round the class one student after another. Students are often encouraged to 
comment on one another's translations, but the teacher invariably ends up stamping his/her authority on a translation, saying whether or not it works, and sometimes providing the students with a model translation. Peter Hutchinson (1977), a lecturer in German, noted that this was the prevailing approach in the 1970s. Anecdotal evidence from a number of UK university modern languages departments suggests that this remains standard practice to this day. Furthermore, Coleman and Klapper (2005: 31) argue that there remains a 'serious discrepancy' between research into language learning and how it is subsequently taught.

Teacher-centred approaches to classroom learning are based on a view of education as the transmission of knowledge from a figure of authority to a relatively passive recipient (McDevitt 1997). They are arguably problematic in several ways: most notably, they do not allow students to develop the process skills required for professional practice (Schön 1983); they disempower students, preventing them from acquiring autonomy and lifelong learning skills (Trilling and Fadel 2009); they can limit the opportunity for students to develop higher order critical thinking skills such as analysis and evaluation (Anderson and Krathwohl 2000; Bloom 1956); and they limit the potential of developing learner autonomy (Broady and Kenning 1996). In the context of translation teaching in $\mathrm{HE}$, the teacher-centred approach therefore potentially undermines what most teachers probably regard as the principal objectives of a translation class: to allow students to understand the processes involved in translation through discussion and debate; to foster students' (self-) critical abilities; and to develop an effective translation style of their own (rather than simply being told what makes a 'good translation'). By physically looking at - and figuratively looking to - the lecturer for reassurance about the quality of their translation, students are unwittingly quashing the critical skills required to make their own judgements, and therefore potentially inhibiting the transition towards becoming autonomous translators. Since there are many different ways of translating the same text effectively, what is required is a teaching approach that encourages greater autonomy and the ability to critique practice. According to Bloom (1956), these are higher order abilities that promote self-evaluation and respect for divergent opinions.

The present study explores an alternative teaching approach based on the principles of studentcentred teaching, whereby students take turns in the place of the 'teacher' (at the front of the class) and the lecturer's role becomes that of the 'expert consultant', present but not central; in other words, a form of peer learning. Based on a careful analysis of the literature on student-centred approaches, we wanted to pilot this approach because we believed it would:

- enhance student interaction;

- promote self- and peer-evaluation and criticism, and hence help students develop higher order (critical and creative) thinking (Bloom 1956);

- help students understand the processes involved in translation;

- and ultimately enable students to improve their competence in translation.

However, we also predicted that there would be resistance from students to this learner-centred approach, and that it would probably require time, trust and willingness on the part of lecturers as well as students, in order to be effective. This form of peer learning, as we discovered, is not a 'quick-fix' approach that can be introduced on a one-off basis. It seems to function best when students have the opportunity to gradually adapt to its expectations and develop familiarity with new classroom roles and attitudes to learning.

\section{Student-centred learning: a review of the literature}

\section{Advocates and critics}

Cornelius-White (2007) suggests that learner-centred teaching has emerged from two principal educational models: the classical, person-centred, humanist model based on empathy, unconditional positive regard, genuineness, non-directivity and the fostering of critical thinking; and the 
contemporary, constructivist model, according to which the construction of knowledge is collaborative and learning is achieved through students' engagement together with different activities (Cornelius-White 2007: 113). Both schools of thought advocate learning that allows a student to be creative, active and able to direct her own thinking as opposed to the mimetic, authoritarian and passive style of traditional teacher-centred practices. Cornelius-White's meta-analysis of 119 studies of learner-centred approaches identified that they were more likely to lead to positive student outcomes. Specifically, he found an unusually high correlation with students' critical and creative thinking; significant increases in participation, satisfaction and motivation to learn; and positive effects on self-esteem and interpersonal skills (130-131).

The learner-centred approach has its roots in 1950s counselling practices, particularly in Rogers' $(1951,1969)$ 'client-centred therapy'. Rogers (1969: 114) advocated the development of skills like critical learning, self-initiation and effective cooperation, as well as creative utilisation of pertinent experience. Crucially, though, he points out that 'facilitation requires at least an initial genuine trust in learners by the facilitator, followed by the creation of an acceptant and empathic climate' (114). Since Rogers' insights, the person-centred approach to psychotherapy has been widely discussed in the context of educational practice. The last two decades have seen the publication of a variety of practical guides to learner-centred teaching, whether for teachers (Doyle 2008; McCombs and Vakili 2005; McCombs and Whisler 1997; Weimer 2013), for administrators (Harris and Cullen 2010), or for both (Blumberg 2012). Others focus on bridging the gap between the theory on learner-centred education and classroom practice (Doyle 2008; Tollefson and Osborn 2007) while still others have conducted studies evaluating the impact of learner-centred teaching in specific institutions (McCabe and O'Connor 2013; McMahon 2011; Osborne 2008).

Educationalists have also dedicated much attention to more specific aspects of student-centred learning, such as discussion (Abercrombie and Terry 1978; Bligh 1986; Brookfield and Preskill 2012; Day 1986; Wells 2009) and group work (Brookfield and Preskill 2012; Bruffee 1999; Cooper 1979; Jacques and Salmon 2012; Joiner 2000; Michaelsen, Knight and Fink 2003). These share the belief that (oral) collaborative learning can have a beneficial effect on cognitive outcomes, motivation, self- and peer-criticism and interdependence. Bruffee (1999: 24) argues that collaboration is central to a good university education, and that university teaching should foster 'willingness to grant authority to peers, courage to accept the authority granted to one by peers, and skill in the craft of interdependence'. However, he also acknowledges that many HE institutions do little to foster these attitudes and skills explicitly.

Though the advocates of student-centred learning far outnumber the detractors, it is important to review, and try to address, the different criticisms before implementing a student-centred approach. A strikingly negative view is adopted by Hirsch (1998: 9), who argues, based on instinct rather than evidence (as he himself acknowledges), that:

Academically focused instruction [is] more engaging and motivating to young learners than learner-centered instruction [... because] individualized, learner-centered instruction must be extremely boring to most students most of the time, since, by mathematical necessity, they are not receiving individualized attention most of the time.

Hirsch's claim that it is logically impossible for all students to receive the personal attention of the teacher throughout a class and that therefore learner-centred approaches must be 'boring', reveals a misunderstanding of what learner-centred approaches are. They are not necessarily about 'individualized' learning, and certainly do not have to involve the teacher giving one-to-one attention to each student throughout the class. Rather, they are about creating an exploratory learning environment where students have greater control over what happens and enter into dialogue with one another to clarify and advance their knowledge and skills.

Hansen and Stephens, while acknowledging the fact that 'the last 10 years have certainly seen a revolution in the ways we talk about student learning' (2000: 41), flag up some more justified difficulties which can undermine the effectiveness of a learner-centred approach: 
- student expectations: 'learned helplessness' and the unwillingness to conduct self-appraisal (42);

- group dynamics: low tolerance for challenges and 'social loafing' (trying to get away with doing less work) (43);

- environmental conditions: political correctness and consumer attitude (44);

- evaluation demands: peer-evaluation anxiety (44) and product fixation (obsession with the end product due to the focus on assessments and marks) (45).

Hansen and Stephens then proceed to consider the moral grounds on which the humanistic model of collaborative learning is based, arguing that this model requires honesty, fairness, courage, care and accountability (45-46). This in turn leads them to offer some guiding principles on which 'growthoriented' learning should be based, such as the fostering of independent learning, a desire to challenge oneself, the courage to be different, and an ability to lead (47). Their point, therefore, is not to dismiss student-centred approaches because of the above constraints and challenges, but rather to encourage teachers to embrace a student-centred model that may clash with students' initial attitudes, but ultimately may lead to greater learner autonomy (Broady and Kenning 1996).

\section{Teaching languages and translation}

Much has been written on the subject of learner-centred teaching in the context of foreign language pedagogy, mainly in the 1980s and 1990s. Translation has been used by some teachers to enhance language learning and the two areas have strong links in historical and practical terms. Translation has been present in language teaching since the 1500s, when the grammar-translation method derived from the disciplines of Latin and Ancient Greek was gradually adopted in the context of foreign language teaching (McLelland 2015). Even when the grammar-translation method was rejected in the context of language teaching in secondary education in the 1960s and 1970s, translation courses remained prevalent in UK-based undergraduate modern languages degrees (Carreres and Noriega-Sánchez 2011).

This continued focus on translation cannot simply be said to be part of an outdated approach to language teaching. Rather, it is recognised that a great number of competences are acquired through translation training and that these are valuable in and beyond foreign language acquisition. They include, most importantly, communicative and textual skills in at least two languages and cultures; intercultural competence; and strategic competence, including problem-solving, self-assessment and revision (Kelly 2005: 32-33).

In the context of foreign language pedagogy, approaches to learner-centred teaching have varied, including notions of autonomy (Broady and Kenning 1996; Brookes and Grundy 1988; Holec 1979; McDevitt 1997), self-instruction (Dickinson 1987), experiential learning (Kohonen 1992), flexible learning (Evans 1993) and learner-centredness (Tudor 1993). What learner-centred approaches have in common is the focus on students taking responsibility for, and playing active roles in, their learning, and a corresponding shift in the role of the teacher from 'purveyors of knowledge' to a less authoritarian (but still authoritative) role of 'facilitator', 'consultant' or 'counsellor' (McDevitt 1997: 36).

Studies on learner-centred teaching approaches have often brought together the arguments of both critics and advocates - that is to say, researchers have recommended learner-centred teaching with a number of reservations and cautions. Cotterall (1995) argues that, before any approaches promoting student autonomy are implemented in the classroom, 'it is necessary to gauge learners' readiness for the changes in behaviour and beliefs which autonomy implies', since these beliefs 'will affect (and sometimes inhibit) learners' receptiveness to the ideas and activities presented in the language class' (1995: 195, 203). Through a study of 139 English as a Second Language (ESL) adult students, Cotterall examines six areas of student beliefs, including the role of the teacher, the role of feedback and learner confidence in study ability. The finding, for example, that $43 \%$ of the group 'like the teacher to tell [them] what to do' (197), suggests that many of the students have not yet reached a state of readiness for autonomous learning. As Cotterall argues, only by exploring, interrogating 
and challenging such beliefs can learners and teachers build a common understanding of the language learning process, which can in turn support greater self-direction (Brookfield 2009).

Building on these notions, McDevitt (1997) stresses the need to prepare and 'train' learners for autonomy, moving away from 'spoon-feeding information to a captive and passive student body' (Raelin 2009: 407). An experiment with the then-new Self-Access Language Learning Centre (McDevitt 1996) demonstrated that, 'to maximise the potential of the facility, learners must be given training in exploiting its resources and encouraged to experiment, and teachers must be available for consultation' (1997: 37). An important point comes out of this study, notably the impact of the attitude and behaviour of the teacher on the success of a learner-centred approach, reinforcing the point made by Rogers (1969) regarding the necessity of the teacher's trust and faith in learners, but also suggesting that (paradoxically, perhaps) it is at least in part the teacher who is responsible for training learners to become more autonomous.

In an article on teaching roles in the learner-centred classroom, Tudor (1993: 25) points out that learner training 'calls for skills which have little to do with language teaching skills in a narrow sense: the skills involved are essentially educational - skills designed to develop understanding and human potential'. On top of the skills required in traditional modes of language teaching, Tudor highlights additional ones, like personal and educational skills (in order to '[evaluate] students' potential and [negotiate] their involvement in a sensitive manner', and to 'shape [students'] ability to make the most of their knowledge and experience') (1993: 29).

Before turning to our own study, let us finally turn to the research conducted on non-traditional teaching methodologies in the specific context of translation teaching. This research has grown recently, even though translation teaching practices still tend to remain teacher- and productfocused. As far back as 1977, Hutchinson suggested supplementing the conventional translation class with group work and a focus on discussion: for example, presenting the class with a 'bad' translation and asking the students to discuss the problems and possible solutions; or asking the class to compare two markedly different translations. Such activities, he argued, could promote problemsolving, encourage critical thinking, and promote student 'enjoyment', and hence engagement (Hutchinson 1977: 26). As he notes: 'it is in class discussion that the richest translations are produced' (29). The pilot approach we report on here goes one step further, building on Hutchinson's ideas of group work. However, the aim is not just to supplement but rather supplant the traditional model. This is attempted by combining product and process through which learning is promoted and the outcome achieved. The process provides an opportunity for the learner to gain a greater awareness of her approach to translation as a learner, rather than focusing upon the final result. Such an approach encourages greater autonomy (Broady and Kenning 1996) and is based on individuals working collaboratively through teaching each other (Lewiset al. 1996; Mazur 1997). Ultimately, this may bridge the gap that can exist between the teacher and the students, leading the latter to take greater responsibility and acknowledging the value of individual frameworks.

Fox (2000: 115) also suggests that 'traditional product-oriented translation methodologies' may be replaced by a 'potentially more effective process-oriented approach'. She proposes using translation diaries to allow students to reflect on the problems they face when tackling particular texts, and demonstrates the effectiveness of this method by tracking the progress of one student through four translation diary entries. As she concludes, the process of reflecting on the act of translating itself (rather than on critiquing the translated product) helps this student to achieve the learning objectives of the course.

Other scholars have borrowed and adapted the notion of a 'task-based approach' from FL pedagogical research (Ellis 2003; Nunan 2004), where students develop their language skills through tasks which engage them in communicative, practical, real-world activities, and which may involve higher cognitive skills like selection, synthesis and evaluation (Carreres and Noriega-Sánchez 2011; González Davies 2004; Hurtado 1999). In the context of business translation teaching, Li (2013) argues that there are challenges posed by task-based approaches. It is important to convince students that there is a 'real need' for translation; that tasks are 'authentic' and activate a range of translation 
competencies; and that both the task outcome and the process undertaken are assessed. Nevertheless, Li argues that there remain significant advantages, including the focus on the translation process rather than the product, the development of reflective practices among students and, ultimately, the activation of translation competence.

Yet, in spite of these significant shifts in pedagogical research, modern languages teachers in $\mathrm{HE}$ still tend to resort to more traditional, product-based approaches. There are many reasons why this might be the case, not least the fact that, quite simply, teachers tend to teach the way they were taught (Cheek and Castle 1981; Chicoine 2004). The current HE climate might also explain this gap between information available from pedagogic research and practice: because lecturers are evaluated primarily on their research output, not on the quality of their language teaching, there is little incentive for developing innovative teaching methods (Carreres 2006). In addition, due to the increased focus on student satisfaction and students as consumers (Hansen and Stephens 2000), it may well be that language lecturers and tutors are afraid to take risks, preferring to replicate models of teaching which are familiar even if they do not reflect the latest pedagogic insights.

\section{Methodology}

This paper examines students' responses to two short experiments in peer learning introduced into traditional translation classes. In both cases, peer learning was implemented as follows: all students prepared their translations as usual for class but at the beginning of the class, one or two students were asked to volunteer to take on the 'teacher' role (they were given the option to take the whole class, or to take it in turns with another student). The 'teaching' student(s) then sat at the computer at the front of the class, asking their peers to volunteer a sentence or paragraph (and selecting contributors when necessary), and then typing the translation into a Word document projected to all students. The other students were thus able to see the translation and to make suggestions, compare their translations or ask one another questions. The teacher sat at the back of the class, present but not central. In this approach, the teacher becomes the 'expert consultant'. If the students misunderstood the source text or were unable to find solutions themselves, the teacher was able to intervene and make suggestions, but otherwise, the class was led by a student or students. Variations included shifting from a whole-group activity to a small-group activity, with the class divided into small groups or pairs who would then pool their individual translations in order to produce an improved version through collaborative work. In the second half of the class, the students were asked to swap their collaborative translations, and to mark one another's work according to the department's marking criteria.

This peer-learning model was piloted in undergraduate translation classes at the University of Surrey, UK, where translation into English is a semester-long (11-week) module at all 3 levels of the undergraduate degree (Years 1-3). Students have one class of two hours every week. Group A $(N=19)$ consisted of students from three Spanish-into-English translation modules in Years 1, 2 and 3 ( $n=6,4$ and 9, respectively), and was run by Lecturer $A$ (the researcher). The three modules were delivered in a teacher-centred style for the first five weeks of the semester, and then in the above peer-learning format for the remaining six weeks. During the teacher-centred sessions, the students were gradually familiarised with a more learner-centred style through the creation of a relaxed, supportive atmosphere, discussion of their work, self- and peer-appraisal and encouragement to make autonomous decisions. Over the six weeks devoted to peer learning, the whole-group format outlined above was followed for most classes, with the small-group variation tested in one class. The Group A classes worked on a variety of texts including biographies, film reviews, recipes and business letters in Year 1; journalistic texts on politics, environment and business, as well as cultural and touristic texts in Year 2; political speeches, literary texts and medical texts in Year 3.

Group B $(N=21)$ was formed of students from Year $2(n=8)$ and Year $3(n=13)$ French-intoEnglish translation classes, working on a similar variety of texts to Group A students. These were taught by Lecturer B throughout the semester. In contrast to Group A, they were delivered for 
most of the semester in a teacher-centred format but the peer-learning format was introduced for a single, one-off session towards the end of the semester. The students were informed in advance of the session. All of the students (from Groups A and B) had worked with their respective teachers (Lecturers A and B) throughout the module, and in many cases in previous modules. Through this familiarity, a relationship of trust had already been built up between students and lecturers, and students from both groups were used to interactive, task-oriented classes with a strong focus on student participation and interaction. This was part of the ethos of the teaching department and was enabled by the small numbers in each class. Nevertheless, for the majority of students, the idea of taking on the role of the 'teacher' was not one they were familiar with. The peer-learning format was thus outside their normal sphere of experience and, probably, their comfort zone. The reason for exploring students' reactions to a one-off session, on the one hand, and a series of sessions, on the other, was to get some idea of students' immediate 'gut reactions' to the approach versus reflections after a longer experience. One of our expectations, based on the literature, was that students do need time to adjust to, and feel comfortable with, student-centred approaches.

The students were asked to evaluate their experience of peer learning by giving written feedback after the peer-learning session or sessions. They were simply asked to report on its advantages and disadvantages for them as learners. This format was designed, in line with the principles of learner-centred teaching, to be as open as possible, giving students the freedom and autonomy to give their own opinions on the subject without being directed by narrowly focused or leading questions. Feedback was voluntary and anonymous. Responses were received from all participants. Lecturer B was also asked to provide feedback (again on a blank sheet) on the experience of teaching the groups.

The data from both student groups were coded to highlight dominant themes reflecting their experience of the learner-centred model. What emerged was a set of 25 key themes: 14 positive themes including interaction, inclusivity and freedom, and 11 negative themes including slow speed, lack of teacher input and uncertainty (see Figures 1 and 2). In addition, Teacher B's feedback was analysed in line with the themes generated from the student feedback.

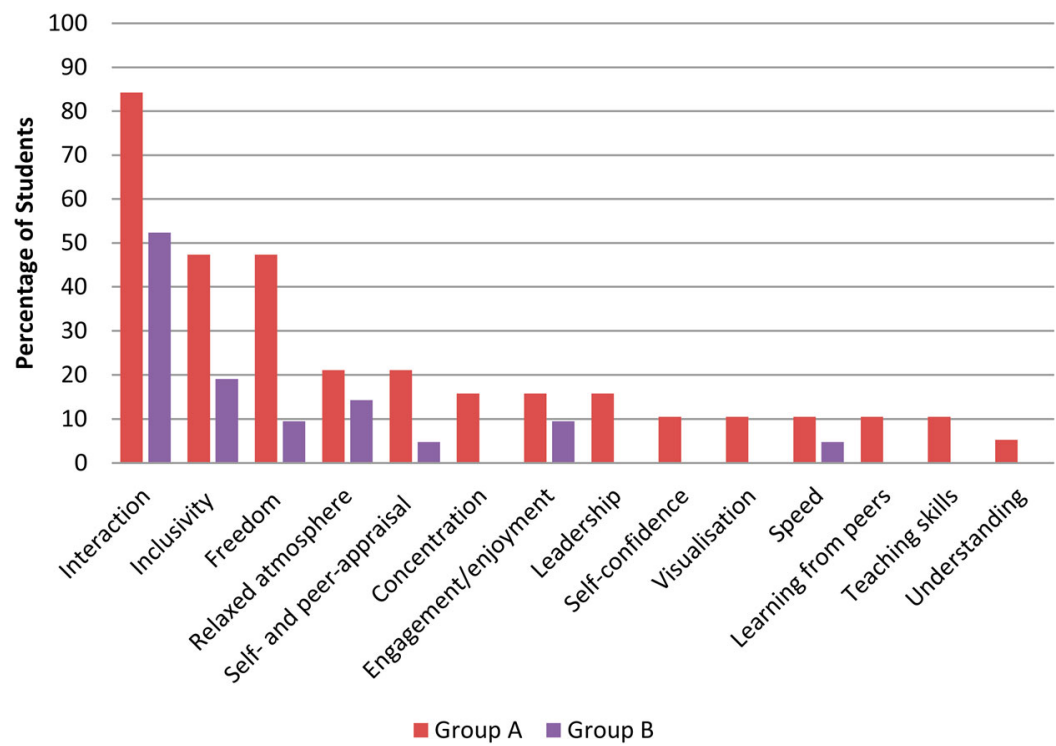

Figure 1. Students' views of the advantages of the learner-centred model. 


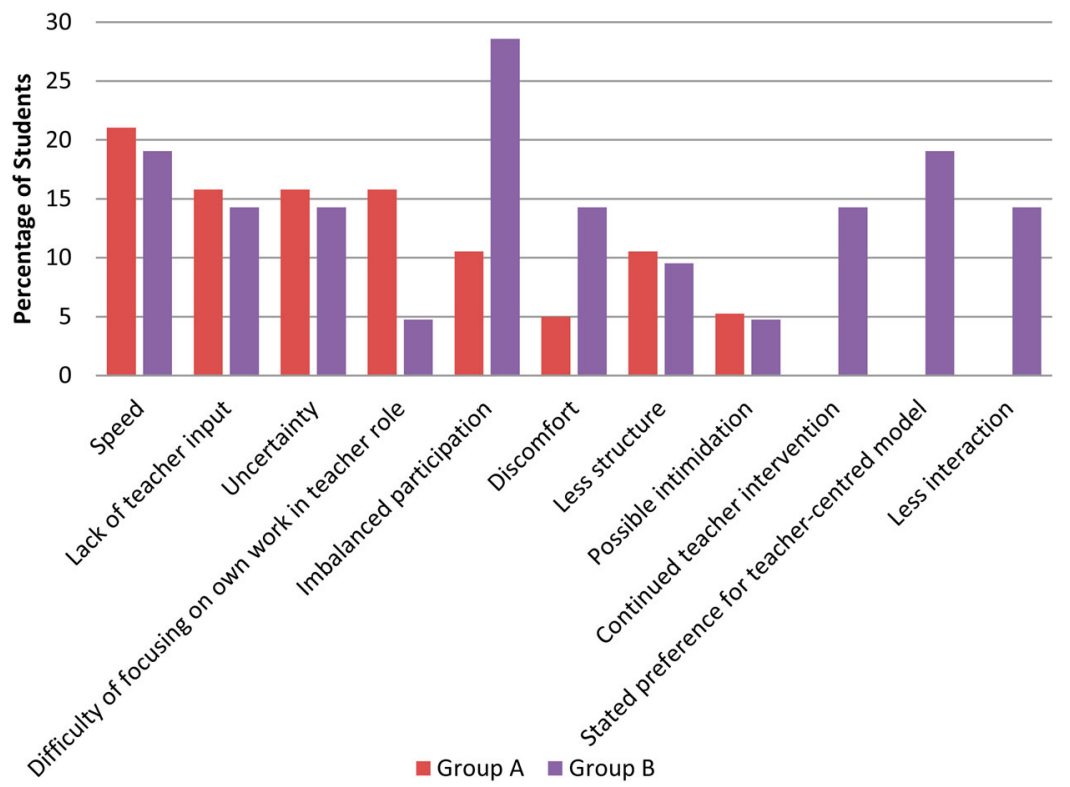

Figure 2. Students' views of the disadvantages of the learner-centred model.

\section{Findings: benefits, drawbacks and contradictions}

As can be seen in Figure 1, the responses of Group A corresponded to many of the expectations of a student-centred approach noted in our analysis of the existing literature. Particularly noteworthy was the students' reported experience of increased interaction, with 16 out of 19 students in Group A $(84 \%)$ reporting this as a positive impact; several students noted the increase in interaction and discussion 'between the students' (A5, A7, A14, A17) or in 'group discussion' (A8) and 'class discussions' (A10). Group A thus appeared to experience the approach as promoting greater student-to-student interaction. In Group B, however, only about half the students noted an increase in interaction, commenting on 'more involvement and participation' (B4), or 'more interaction, discussion and involvement' (B13), though sometimes tentatively: 'perhaps more interaction' (B18).

Inclusivity was another positive feature highlighted by nine students (just under half the group) in Group A. They noted a greater number of students participating ('involves more members of the class', A18) and an atmosphere in which shyer students felt able to contribute ('quieter students able to share their ideas', A15; 'more contribution from shyer students', A16). The feeling of increased inclusivity was mentioned by four students (19\%) from Group B: as one student reported, the learnercentred approach 'means everyone, including quieter students, gets talking' (B5). This linked to a further theme identified by four students (21\%) from Group A and three (14\%) from Group B: the 'more relaxed' (A6), 'more comfortable' (B17), 'less intimidating' atmosphere (B16, A17), in which students were able to communicate more because they felt under 'less pressure' (A17) and were 'less worried about getting something wrong' (A6).

The third key theme that recurred in about 50\% of Group A's feedback is that of freedom. This takes different forms: for some students, the learner-centred approach allowed students to speak up 'when they want' (A8); for others, it provided 'more freedom for students to give their opinions' (A14). This, they considered, had the knock-on effect of 'allow[ing] other styles to be incorporated' (A18), integrating 'different approaches' (A19) and permitting 'reflect[ion] on translation style differences' (A9). In turn, this space for reflection, combined with more sustained interaction between students and a more relaxed atmosphere, led over a fifth of Group A students to notice an increase in self- and peer-appraisal, debate and criticism: students 'question one another's translations' (A1) and 
have a 'chance for self-assessment' (A7). This finding chimes with Little's (2007) insistence on the importance not only of learner involvement, but also of learner reflection. Learning may begin with dialogue between teachers and students or between student peers, but this should then foster students' internal processes of inner speech or discursive thinking (Vygotsky 1978) when they are engaged in an individual task such as an assignment, an examination, and eventually perhaps a professional translation task.

Other positive themes, highlighted by fewer students from both groups, include a heightened level of concentration and an improvement in listening skills (16\%); an engaging, fun and lighthearted learning environment (16\%); a beneficial focus on leadership skills as a result of having to take the 'teacher's role' (16\%); and increased self-confidence, particularly as a result of taking a position of leadership (11\%). Finally, two students in Group A (11\%) noted that they felt the approach enabled them to 'visualise' the task in progress. Usually, the translation process utilised by peers is a 'silent' one where only the final product is exposed. Here, where the student becomes the teacher, the students believed that there was greater visualisation of the thinking process as it is verbalised. Those present are therefore able to 'see' the thinking process of the students rather than just the end product, contributing to McDevitt's notion of giving students a stake in the process of learning (cited above).

We shall now turn to the perceived disadvantages of the peer-learning approach. As is clear from Figures 1 and 2, there was a difference between responses in Group A and in Group B, as we predicted. Group A's responses tended overall to be more strongly positive. The negative themes were less widely represented than the positive ones: of the 11 negative themes, only 4 were mentioned by more than 3 students (16\%), compared to 8 of the 14 positive aspects. While three of the positive themes were highlighted by half of the group or more, none of the negative themes were mentioned by more than four students.

Group B's responses suggested that this group of students may have experienced the negative aspects of the one-off peer-learning session as outweighing the positive, with eight negative aspects being mentioned by three or more of students, compared to only three positive aspects. Overall, there was a much greater focus on negative aspects in Group B's feedback. Three students (B2, B3, B8 - 14\%) mentioned no positive aspects at all while five (B6, B7, B8, $\mathrm{B} 11, \mathrm{~B} 20-24 \%)$ stated a definite preference for the teacher-centred approach, as illustrated in the following examples:

I don't believe that the lecturer, who has experience in this field, should be sat at the back, otherwise it just becomes an organised discussion amongst students. (B20)

I prefer having the teacher at the front of the class, as she will be the one assessing our work. I feel it is that opinion that is more important. However, so long as she still gives her input throughout the lesson, it does work. (B11)

These comments highlight the challenges posed by peer learning and the resistance with which it can initially be met. Though the second comment is nuanced, both these students from Group B emphasise the value of the teacher's viewpoint over that of a peer, either because of the teacher's experience or because of their authority as the assessor. This is entirely rational given the assessment approach. However, if an aim is for each learner to become more self-aware and autonomous, then as teachers, we need to explore how the student can be supported to take on greater responsibility to assess for themselves. Other related negative factors (mentioned by around $15 \%$ from both groups) are the lack of teacher input, expressed in statements like 'students can't say whether people are wrong or right' (B2) or that 'the teacher does know best' (A11); and the lack of certainty or clarity, as students 'may not know if a suggestion is good or not' (A13), might be 'less confident with [the] outcome of [a] translation' (A16) or 'less clear on what the actual answer is' (B17). It was interesting to note that four students found that focusing on their own work was difficult when acting in the role of teacher. In addition, four students from both groups were concerned that the 'speed' of the session was problematic when peers were in the teacher role. Whilst these initially are reported as 
negative, it may be that greater engagement with this model of teaching could help to turn this into a more positive response.

There were also contradictory responses between and within the groups. While most students reported a sense of increased interaction in the peer-learning class, some in Group B noted the opposite. Similarly, even though inclusivity (i.e. the engagement of all students) is generally thought to be a strength of a learner-centred model, some students (eight altogether, six from Group B) felt that student participation was uneven, with some students contributing more than others, or shyer students avoiding participation altogether. In the same vein, while peer learning seemed to be associated with a more relaxed classroom atmosphere for some (four students or $21 \%$ of Group A, three students or $14 \%$ of Group B), others reported a feeling of discomfort or possible intimidation (one member of Group A, three members of Group B).

\section{Overcoming difficulties: time, trust and techniques}

We deliberately surveyed students after two different 'deliveries' of peer learning: a block of six classes in the case of Group A, and a one-off session in the case of Group B. Our findings suggest a much less positive reaction from Group B, compared with Group A, and a plausible explanation for this may be the lack of opportunity afforded to Group B to familiarise themselves with the peer-learning approach, to experience it and evaluate its positive and negative aspects over a longer period of time. From this conclusion, we draw three suggestions for implementing peer learning more successfully: allowing time for adaptation to new roles and new procedures; cultivating an atmosphere of trust (between teacher and students and between peers); and changing methods of assessment (and corresponding attitudes).

\section{Allowing time for adaptation}

Students require time, training and readiness to engage in new learning formats, particularly when these imply learner-centred and active learning (Cotterall 1995; McDevitt 1997). Three students in Group B reported experiencing discomfort in the peer-learning class compared with only one student in Group A. The concerns voiced by the members of Group B - that 'class members feel uncomfortable with a classmate leading the class' (B5) or that students may 'be reluctant to go up in front of peers' (B17) - were not raised by any members of Group A, who had the opportunity to experience new roles on repeated occasions and thus may have been able to overcome any anxieties. Conversely, two students in Group A mention how the peer-learning approach helped their self-confidence, a view not mentioned by any students in Group B. It could be that the feelings of discomfort experienced by three Group B students were behind the perception, also reported by three Group B students, of reduced interaction in the peer-learning class as compared with their usual teacher-centred classes. As one of the Group B students put it: 'everyone seem[ed] less forthcoming, [for] fear of treading on [the] toes of [their] classmates' (B5). This point did not appear in Group A's feedback.

Another issue raised in Group B, but not in Group A, concerned what some students perceived as problematic aspects of the teacher's behaviour during the peer-learning lesson. Three students (14\%) reported feeling that the teacher intervened in such a way as to dominate the lesson, thus upsetting the dynamic of the group, undermining the student-leader and perpetuating traditional roles. The teacher of Group B had not received any specific training in supporting peer learning, and also did not have the opportunity to become familiar herself, beyond the one-off class, with the changes in classroom dynamics implied by peer learning. This highlights the importance for both teacher and students of ensuring a period of adaptation to any new learning approach, and in particular, learner-centred learning with its emphasis on students taking greater responsibility for the management of their own learning. 


\section{Cultivating an atmosphere of trust}

Connected with the issue of time, the more nebulous issue of trust might go some way to explaining the qualitative difference between the learning experience of Groups A and B. We return to Rogers' point that facilitation requires 'at least an initial genuine trust in learners by the facilitator' (1969: 114). Interestingly, there was a clear parallel between some of the feedback from Group B students and Teacher B's comments, presented below:

- Can be difficult to refrain from intervening, for various reasons:

- Students may misunderstand the source text and be unaware of it OR unwilling to point out that another student has misunderstood;

- Students do not necessarily realise that there IS an issue to be discussed;

- They may be unwilling to correct or criticise a poor solution;

- They lack certainty.

- Some students are very good at taking a lead; some are not.

Clearly, the effectiveness of a student-centred approach is determined not only by student beliefs and attitudes (Cotterall 1995), but also by the teacher's attitude and behaviour, as well as their confidence in the students' ability, and willingness to set high expectations (Chickering and Gamson 1999; McDevitt 1997). It is important to acknowledge here that in Group B, with peer learning being used for a one-off session only, neither teacher nor students had much opportunity to make it work.

In a successful peer-learning approach to the translation class, even if some students misunderstand the target text, others are often able to correct, explain and propose an alternative translation. As Liu and Carless (2007) have pointed out, however, this peer-appraisal and feedback (mentioned by four students or $21 \%$ in Group A but by only one in Group B) requires a teaching context in which 'positive and trusting peer relations exist; and a collaborative learning climate has been established' (Liu and Carless 2007: 288). Lack of confidence in one's peers arguably leads to other negative features of student-centred learning identified by Group B: imbalanced participation and lack of interaction (because students do not feel they can speak out, especially in criticism of a peer); dissatisfaction with the lack of teacher input and resulting uncertainty (because students do not trust their peers and, as Bruffee (1999) points out, 'willingness to grant authority to peers' is a quality learnt through group work); continued teacher intervention (because the teacher does not trust the students and the students do not trust one another); and discomfort (because the students are afraid to lead or to criticise their peers).

Another way out of the deadlock, resulting from the polarisation of teachers as experts and students as amateurs, may be to shift the emphasis, as suggested by Palmer (1998: 102), from a studentcentred approach to a subject-centred approach, whereby teacher and students become 'knowers', all interacting directly with the subject itself, and to other learners, not necessarily through the teacher. In the context of a translation class, the focal point would therefore not be the student leader, but rather the translation process itself in which all of the 'knowers' would take part. The emphasis is on learning from the process and not on the final 'answer'. The group act together as a 'circular, interactive, and dynamic [...] community of truth' (1998: 103). According to Palmer (2004), this 'circle of trust' occurs when relationships are clear and dialogue connects people effectively together.

It must be acknowledged, however, that a certain circular logic seems to link trust and collaboration. In relation to assessment methods, Carless (2009) suggests that one way of developing trust between staff members is through increased collaboration, openness and transparency. If this notion is extended to student-teacher and peer-peer relations, it implies that as well as the collaborative learning environments being built on trust, trust is also built on collaborative learning. This situation arguably brings us back to the first point: it is only over time that teacher-directivity 
and lack of confidence in one's peers can be replaced by confident peer-to-peer learning, as learners understand how knowledge and skill can be effectively built through collaboration and consultation.

\section{Altering assessment methods}

Two other legitimate concerns emerged from the student feedback in both groups: first, the notion that there is a 'correct' answer, with the associated expectation that this is what the teacher imparts; and second, a recurring concern with the lack of input by the person marking the assignments. These correspond to a problem identified by Hansen and Stephens (2000): what they call 'product fixation' which can result from excessive focus on assessments and marks. It may therefore be necessary to consider ways to enhance assessment of the process to offset these concerns. One way may be by looking to the literature on assessment and feedback to determine how to encourage students to be partners in this process. Looking at the data collected here in Group A, a number of positive outcomes appeared that may counterbalance some concerns. For example, students' growth in self-confidence and in higher order thinking correlated with their ability to make more informed judgement about their knowledge and how this can be applied, ultimately moving towards greater autonomy. To further alleviate students' anxieties on these two issues, students might be given one or more possible translations by 'experts' such as the teacher to view and discuss at the end of the class. There is, however, a danger with this approach, in that it may well undermine the process of peer learning as students simply wait to see the expert translation. An approach more consistent with the principles of peer-to-peer learning could be the implementation of peer feedback or even peer assessment, whose various merits have been increasingly acknowledged in recent years (Nicol, Thomson and Breslina 2014). This method would not only promote peer-appraisal (and consequently self-appraisal) and critical thinking, but also give the students a sense of control over the process of validation and assessment. Currently, there is a sense of assessment as 'done to' learners not 'done with', which, according to Carless (2009), creates a sense of distrust. A move towards greater student involvement on assessment may be a valuable outcome (Falchikov 2005), leading towards greater self-assessment (Boud 1995) and learner autonomy (Broady and Kenning 1996).

\section{Conclusion}

This small-scale action research study is inevitably limited by the specific teaching context in which it was conducted. It focused on very small numbers and a single source of self-report data. However, it reflects in some detail on an attempt to introduce peer learning into an area of language practice which has traditionally been highly teacher-centred and concludes that with time, trust and techniques, this approach to peer learning in translation classes can be effective. Further research could usefully explore in greater depth and with greater precision the way in which students engage with translation through peer learning (and whether/how this engagement leads to effective learning) and also the extent to which, and how, student attitudes to such peer learning change over time. A detailed investigation of effective teacher roles in the context of the peer-learning translation class would also be particularly helpful.

\section{Acknowledgements}

The authors would like to thank their Languages colleagues at the University of Surrey for supporting this project, but also all the Languages students who took part in the project. In addition, they would like to express their sincere gratitude to the two reviewers for their critical, insightful and constructive comments on an earlier version of the article.

\section{Disclosure statement}

No potential conflict of interest was reported by the authors. 


\section{References}

Abercrombie, M.L.J. and Terry, P.M. 1978. Talking to Learn. Guildford: Society for Research into Higher Education.

Anderson, A. and D. Krathwohl. 2000. A Taxonomy for Learning, Teaching and Assessing: A Revision of Bloom's Taxonomy of Educational Objectives. New York: Allyn \& Bacon.

Bligh, D.A. 1986. Teach Thinking by Discussion. Guildford: SRHE \& NFER-Nelson.

Bloom, B.S. 1956. Taxonomy of Educational Objectives, the Classification of Educational Goals - Handbook I: Cognitive Domain. New York: McKay.

Blumberg, P. 2012. Developing Learner-Centered Teaching: A Practical Guide for Faculty. San Francisco, CA: John Wiley.

Boud, D. 1995. Enhancing Learning Through Self-Assessment. London: Routledge Falmer.

Broady, E. and M.-M. Kenning. 1996. Promoting Learner Autonomy in University Language Teaching. London: AFLS and CiLT.

Brookes, A. and P. Grundy. 1988. Individualisation and Autonomy in Language Learning. London: British Council/Modern English.

Brookfield, S.D. 2009. Self-directed learning. In International Handbook of Education for the Changing World of Work, ed. R. Maclean and D. Wilson, 2615-2627. Dordrecht: Springer.

Brookfield, S.D. and S. Preskill. 2012. Discussion as a Way of Teaching: Tools and Techniques for Democratic Classrooms. San Francisco, CA: John Wiley.

Bruffee, K.A. 1999. Collaborative Learning: Higher Education, Interdependence, and the Authority of Knowledge. Baltimore, MD: Johns Hopkins University Press.

Carless, D. 2009. Trust, distrust and their impact on assessment reform. Assessment \& Evaluation in Higher Education 34 , no. 1: 79-89.

Carreres, A. 2006. Strange bedfellows: translation and language teaching. Canadian Translators, Terminologists and Interpreters Council. http://www.cttic.org/ACTI/2006/papers/Carreres.pdf (accessed 17 May, 2016).

Carreres, A. and M. Noriega-Sánchez. 2011. Translation in language teaching: insights from professional translator training. The Language Learning Journal 39, no. 3: 281-97.

Cheek, H. and K. Castle. 1981. The effects of back-to-basics on mathematics education. Contemporary Educational Psychology 6, no. 3: 263-77.

Chickering, A.W. and Z.F. Gamson. 1999. Development and adaptations of the seven principles for good practice in undergraduate education. New Direction for Teaching and Learning 80: 75-81.

Chicoine, D. 2004. Ignoring the obvious: a constructivist critique of a traditional teacher education program. Educational Studies Journal of the American Educational Studies Association 36, no. 3: 245-63.

Clavijo, B. and P. Marin. 2013. Identifying translation teaching strategies. International Journal of Humanities and Social Science 3, no. 21: 71-8.

Coleman, J.A. and J. Klapper. 2005. Effective Learning and Teaching in Modern Languages. London: RoutledgeFalmer.

Cooper, C.L. 1979. Learning from Others in Groups: Experiential Learning Approaches. London: Associated Business Press.

Cornelius-White, J. 2007. Learner-centered teacher-student relationships are effective: a meta-analysis. Review of Educational Research 77, no. 1: 113-43.

Cotterall, S. 1995. Readiness for autonomy: investigating learner beliefs. System 23, no. 2: 195-205.

Day, R.R. 1986. Talking to Learn: Conversation in Second Language Acquisition. Rowley, MA: Newbury House.

Dickinson, L. 1987. Self-Instruction in Language Learning. Cambridge: Cambridge University Press.

Doyle, T. 2008. Helping Students Learn in a Learner-Centered Environment: A Guide to Facilitating Learning in Higher Education. Stirling, VA: Stylus.

Ellis, R. 2003. Task-based Language Learning and Teaching. Oxford: Oxford University Press.

Evans, M. 1993. Flexible learning and modern language teaching. The Language Learning Journal 8, no. 1: 17-21.

Falchikov, N. 2005. Improving Assessment Through Student Involvement. London: RoutledgeFalmer.

Fox, O. 2000. The use of translation diaries in a process-oriented translation teaching methodology. In Developing Translation Competence, ed. C. Schäffner and B. Adab, 115-130. Amsterdam: John Benjamins.

González Davies, M. 2004. Multiple Voices in the Translation Classroom. Amsterdam: John Benjamins.

Hansen, E.J. and J.A. Stephens. 2000. The ethics of learner-centered education: dynamics that impede the process. Change: The Magazine of Higher Learning 32, no. 5: 40-7.

Harris, M. and R. Cullen. 2010. Leading the Learner-Centered Campus: An Administrator's Framework for Improving Student Learning Outcomes. San Francisco, CA: John Wiley \& Sons.

Hirsch, E.D. 1998. Reality's revenge: research and ideology. Arts Education Policy Review 99, no. 4: 3-15. http://home.gwu. edu/ pryder/English11_S02/Hirsch--on\%20Grasci\%20\&\%20Friere.htm (accessed 4 February, 2016).

Holec, H. 1979. Autonomy and Foreign Language Learning. Strasbourg: Council of Europe.

Hutchinson, P. 1977. Improving the standard of translation. Modern Languages, Journal of the Modern Languages Association 83: 24-30.

Hurtado Albir, A. 1999. Enseñar a traducir. Madrid: Edelsa.

Jacques, D. and G. Salmon. 2012. Learning in Groups: A Handbook for Face-To-Face and Online Environments. Abingdon: Routledge. 
Joiner, R. 2000. Rethinking Collaborative Learning. London: Free Association Press.

Kelly, D. 2005. A Handbook for Translator Trainers: A Guide to Reflective Practice. Manchester: St Jerome.

Kiraly, D. 2001. A Social Constructivist Approach to Translator Education. Abingdon: Routledge.

Kohonen, V. 1992. Experiential language learning: second language learning as cooperative learner education. In Collaborative Language Learning and Teaching, ed. D. Nunan, 14-39. Cambridge: Cambridge University Press.

Lewis, T., J. Woodin and E. St John. 1996. Tandem learning: independence through partnership. In Promoting Learner Autonomy in University Language Teaching, ed. E. Broady and M.-M. Kenning, 105-120. London: AFLS and CiLT.

Li, D. 2013. Teaching business translation. The Interpreter and Translator Trainer 7, no. 1: 1-26.

Little, D. 2007. Language learner autonomy: some fundamental considerations revisited. Innovation in Language Learning and Teaching 1, no. 1: 14-29.

Liu, N.F. and D. Carless. 2007. Peer feedback: the learning element of peer assessment. Teaching in Higher Education 11, no. 3: 279-90.

Mazur, E. 1997. Peer Instruction: A User's Manual. Upper Saddle River, NJ: Prentice Hall.

McCabe, A. and U. O'Connor. 2013. Student-centred learning: the role and responsibility of the lecturer. Teaching in Higher Education 19, no. 4: 350-9.

McCombs, B.L. 2008. Effective Learner-Centered Classroom Practices: A Compendium of Effective Practices. San Antonio, TX: Murguia Learning Institute.

Mccombs, B. and D. Vakili. 2005. A learner-centered framework for e-learning. Teachers College Record 107, no. 8: 1582600.

McCombs, B.L. and J.S. Whisler. 1997. The Learner-Centered Classroom and School: Strategies for Increasing Student Motivation and Achievement. San Francisco, CA: Jossey-Bass.

McDevitt, B. 1996. The self-access language learning centre, University of Dundee: history of a project. The Language Learning Journal 13: 67-9.

McDevitt, B. 1997. Learner autonomy and the need for learner training. The Language Learning Journal 16, no. 1: 34-9.

McLelland, N. 2015. German Through English Eyes: A History of Language Teaching and Learning in Britain, 1500-2000. Wiesbaden: Harrassowitz.

McMahon, E.C. 2011. Learner-centered instruction at a small community college: faculty perceptions. PhD diss. Capella University.

Michaelsen, L.K., A.B. Knight, and L.D. Fink. 2003. Team-Based Learning: A Transformative Use of Small Groups. Stirling: Stylus.

Nicol, D., A. Thomson and C. Breslina. 2014. Rethinking feedback practices in higher education: a peer review perspective. Assessment \& Evaluation in Higher Education 39, no. 1: 102-22.

Nunan, D. 2004. Task-based Language Teaching. Cambridge: Cambridge University Press.

Osborne, L.Y. 2008. Adult Students and Learner-Centered Instruction at a Small Community College: A Mixed Method Study. Ann Arbor, MI: ProQuest.

Palmer, P.J. 1998. The Courage to Teach. San Francisco, CA: Jossey-Bass.

Palmer, P.J. 2004. A Hidden Wholeness: The Journey Toward an Undivided Life. San Francisco, CA: John-Wiley \& Sons.

Prosser, M. and K. Trigwell. 1999. Understanding Learning and Teaching. Buckingham: SRHE and Open University Press.

Raelin, J.A. 2009. The practice turn-away: forty years of spoon feeding in management education. Management Learning 40: 401-10.

Rogers, C. 1951. Client-Centred Therapy: Its Current Practices, Implications and Theory. London: Constable.

Rogers, C.R. 1969. Freedom to Learn. Columbus: Merrill.

Schön, D.A. 1983. The Reflective Practitioner: How Professionals Think in Action. New York: Basic Books.

Tollefson, K. and M.K. Osborn. 2007. Cultivating the Learner-Centered Classroom: From Theory to Practice. London: Corwin Press.

Trilling, B. and C. Fadel. 2009. 21st Century Skills, Learning for Life in our Times. San Francisco, CA: Jossey-Bass.

Tudor, I. 1993. Teacher roles in the learner-centred classroom. English Language Teaching Journal 47, no. 1: $22-31$.

Vygotsky, L.S. 1978. Mind in Society. Cambridge, MA: Harvard University Press.

Weimer, M. 2013. Learner-Centered Teaching: Five Key Changes to Practice. San Francisco, CA: John Wiley \& Sons.

Wells, G. 2009. The Meaning Makers: Learning to Talk and Talking to Learn. Bristol: Multilingual Matters. 